\title{
REVIEW
}

\section{A Guide for the Use of the Ferret Model for Influenza Virus Infection}

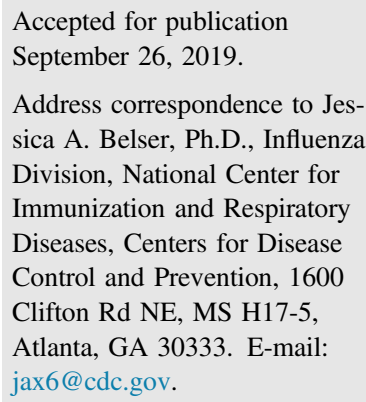

\begin{abstract}
As influenza viruses continue to jump species barriers to cause human infection, assessments of disease severity and viral replication kinetics in vivo provide crucial information for public health professionals. The ferret model is a valuable resource for evaluating influenza virus pathogenicity; thus, understanding the most effective techniques for sample collection and usage, as well as the full spectrum of attainable data after experimental inoculation in this species, is paramount. This is especially true for scheduled necropsy of virus-infected ferrets, a standard component in evaluation of influenza virus pathogenicity, as necropsy findings can provide important information regarding disease severity and pathogenicity that is not otherwise available from the live animal. In this review, we describe the range of influenza viruses assessed in ferrets, the measures of experimental disease severity in this model, and optimal sample collection during necropsy of virus-infected ferrets. Collectively, this information is critical for assessing systemic involvement after influenza virus infection in mammals. (Am J Pathol 2020, 190: 11-24; https://doi.org/10.1016/j.ajpath.2019.09.017)
\end{abstract}

Ferrets are an indispensable model for the study of respiratory viruses in general and influenza viruses in particular. ${ }^{1,2}$ Although no small mammal model can fully emulate human lung pathobiology, ferrets and humans possess similarities in lung physiology and anatomic distribution of sialylated glycan receptors throughout the respiratory tract, ${ }^{3}$ and the glycomic profiles of ferret respiratory tissue more closely align with those of humans compared with other available animal models, such as mice or swine. ${ }^{4,5}$ Human and zoonotic influenza viruses exhibit similar patterns of virus attachment in upper and lower respiratory tract tissues of both humans and ferrets. ${ }^{6}$ Ferrets are, therefore, susceptible to infection with human and zoonotic influenza viruses, without the need for prior host adaptation. Furthermore, ferrets display many of the clinical signs seen in human influenza viral infection, which are not seen in other small mammal models, like mice and guinea pigs. ${ }^{7,8}$

Many public health and basic research activities pertaining to influenza rely on data generated from ferrets. The evaluation of influenza virus pathogenicity and transmissibility in the ferret is considered in risk assessment algorithms for pandemic preparedness, ${ }^{9,10}$ in verification of virulence attenuation of candidate vaccine viruses, ${ }^{11}$ and as a preclinical model for investigating novel vaccine approaches and antiviral treatments. ${ }^{12,13}$ Evaluation of these properties in immunocompromised ferrets (after pregnancy, treatment with immunosuppressive drugs, or other approaches) can provide valuable information about differential disease severity and transmission dynamics, emergence of drugresistant virus variants, and the efficacy of vaccine and antiviral treatments in immunocompromised populations. ${ }^{14-17}$ More important, sequencing of the ferret genome has facilitated the development of species-specific reagents and tools

\footnotetext{
Supported by the Centers for Disease Control and Prevention.

The findings and conclusions in this report are those of the authors and do not necessarily reflect the official position of the Centers for Disease Control and Prevention/the Agency for Toxic Substances and Disease Registry.

Disclosures: None declared.
} 
to further improve the utility of this species in infectious disease research. ${ }^{18}$

The study of influenza virus-infected ferrets in laboratories worldwide clearly represents a valuable asset to the field. Evaluation of similar viruses in different laboratories can greatly improve our understanding of virus pathogenicity, by identifying common features and better elucidating the contribution of virus strain, procedural, and environmental confounders. ${ }^{19,20}$ Collectively, these confounders result in heterogeneity with regard to procedures and practices established at all levels of research, from individual investigators or institutions to broad countryspecific regulations. As most studies using the ferret model use generally similar approaches to assess viral burden, systemic spread, and disease severity after virus challenge (as will be discussed in more detail below), we herein provide practical sample collection and assessment approaches for veterinary professionals and laboratorians working with influenza virus-infected ferrets. We describe general differences in virulence among a wide range of human and zoonotic influenza viruses evaluated in ferrets and identify clinical signs most frequently monitored. Specifically, we provide an overview of samples collected during necropsy and discuss different downstream, laboratory-based applications using these samples. The information is meant as a guide to inform and supplement laboratory- and research-based decisions; deviation from suggestions or typical protocols may be of benefit, depending on the particular questions addressed. Understanding which samples are most critical depending on the type of influenza virus examined, the anticipated viral loads in each tissue, and the intended post-necropsy sample analyses desired will enable researchers to optimize and refine experimental designs and glean the most information possible from experimentation in this species.

\section{Scope of Influenza Viruses Evaluated in Ferrets}

The family Orthomyxoviridae contains multiple genera of influenza viruses. Although influenza A viruses cause the highest burden of disease in humans, influenza B viruses (which circulate almost exclusively in humans) are also associated with morbidity and mortality. ${ }^{21}$ Unlike influenza A viruses, influenza $B$ viruses have not been extensively studied in ferrets, but have been reported to cause mild to moderate disease. ${ }^{22}$ Although influenza $\mathrm{C}$ viruses have been associated with human infection, ${ }^{23}$ and influenza $\mathrm{D}$ viruses are associated with cattle and feral swine infection, ${ }^{24}$ neither are frequently studied in mammalian models. Accordingly, most of the information presented herein pertains to the study of influenza A virus infection in ferrets.

Wild aquatic birds are the natural hosts of influenza A viruses and are classified on the basis of their surface glycoproteins, hemagglutinin and neuraminidase. To date, 16 hemagglutinin and 9 neuraminidase subtypes have been identified in birds. ${ }^{25,26}$ Influenza A virus infections are typically asymptomatic in birds, and they are termed low pathogenic avian influenza (LPAI) viruses. However, the high mutation rate of influenza viruses facilitates emergence of highly pathogenic avian influenza (HPAI) viruses, which can cause up to $100 \%$ mortality in both wild and gallinaceous (terrestrial) birds. More important, influenza A viruses can cross species barriers to cause mammalian infections. Over time, this phenomenon has led to established influenza virus lineages in numerous mammalian species (including humans, swine, and equids). ${ }^{27}$ As humans are immunologically naïve to most zoonotic influenza viruses, sporadic infection with zoonotic viruses represents a persistent public health threat. To improve pandemic preparedness, novel influenza viruses associated with human infection are frequently evaluated in the ferret model to assess their relative pathogenicity and transmissibility, as are laboratoryderived recombinant and reassortant viruses. ${ }^{28,29}$ As mammalian virulence is a polygenic trait, it is not possible to fully predict the disease outcome of a particular strain outside of a living host.

The intravenous pathogenicity index used to classify avian influenza viruses as low or high virulence (LPAI or HPAI, respectively) is assessed by lethality in chickens, ${ }^{30}$ and it represents an independent measurement from mammalian pathogenicity. Some HPAI H5 and H7 subtype viruses cause only mild illness in ferrets, ${ }^{20,31}$ whereas selected LPAI viruses (eg, H7N9) are capable of moderate to severe and fatal disease in mammals. ${ }^{32}$ Although HPAI viruses are more often associated with enhanced virulence in ferrets compared with LPAI viruses, intravenous pathogenicity index tests in chickens are not predictive of mammalian virulence. Similarly, virulence determinations in other small mammal models may not always be predictive of virulence in ferrets; viruses that cause moderate disease in ferrets may cause lethality in mice at comparable inoculum doses, ${ }^{33}$ whereas the guinea pig model does not recapitulate the high virulence phenotype of $\mathrm{H} 5 \mathrm{~N} 1$ viruses or the reconstructed 1918 H1N1 virus. ${ }^{34}$

\section{Assessment of Influenza A Disease Severity in Ferrets}

After influenza virus infection, ferrets may exhibit clinical signs, the scope and severity of which can vary greatly depending on the virus strain, the inoculation dose and route, and other factors. ${ }^{19}$ Measurements of morbidity (as measured by weight loss) and fever (as measured by an increase in preinoculation body temperature) are collected daily and represent the most frequently reported parameters. Ferrets inoculated with most influenza viruses of low mammalian virulence, including seasonal influenza viruses, most LPAI, and variant $\mathrm{H} 1$ and $\mathrm{H} 3$ influenza viruses, exhibit transient fever and mildto-moderate weight loss (generally $<15 \%$ of preinoculation weight) (Table 1). In contrast, influenza viruses that exhibit 
high virulence in this species (eg, select HPAI H5N1 viruses) can cause severe, systemic disease, including sustained high fever $\left(\geq 40^{\circ} \mathrm{C}\right)$ and moderate-to-severe weight loss $(>15 \%$ of preinoculation weight). Lethargy or activity level may be captured quantitatively with specialized equipment and software or via the use of standardized assessment scales by an observer. ${ }^{7}$ Development of additional clinical signs, including neurologic complications, is possible in ferrets infected with highly virulent viruses (Table 1). Additional parameters that align with features of human infection may also be documented, but they are not uniformly present after infection with all viruses and, as such, vary in their frequency of monitoring and reporting in the literature. Many parameters are commonly associated only with highly virulent viruses (Table 1).

Serial specimen collection from inoculated ferrets is critical for characterizing viral replication and shedding kinetics over time. Study designs typically include daily clinical assessment of ferrets, with sample collection typically under anesthesia during a 1- to 2-week period, and/or euthanasia at a predetermined time point (generally day 3 after inoculation or when peak virus replication is believed to occur, depending on the specific experimental design). Nasal washes or nose/throat swabs, typically collected every 24 to 48 hours from anesthetized ferrets, provide a reliable indicator of virus replication in the upper respiratory tract, as positive viral culture of these specimens has been associated with the infectious period in ferrets. ${ }^{35}$ Nasal wash or swab specimens can also provide additional information about the inflammatory response in the upper respiratory tract, such as relative production of cytokines and chemokines and quantification of lymphocyte populations. ${ }^{36,37}$ Collection of swab specimens from extrapulmonary sites, such as rectal or

Table 1 Detection and Reporting of Clinical Signs of Influenza Virus Infection in Ferrets

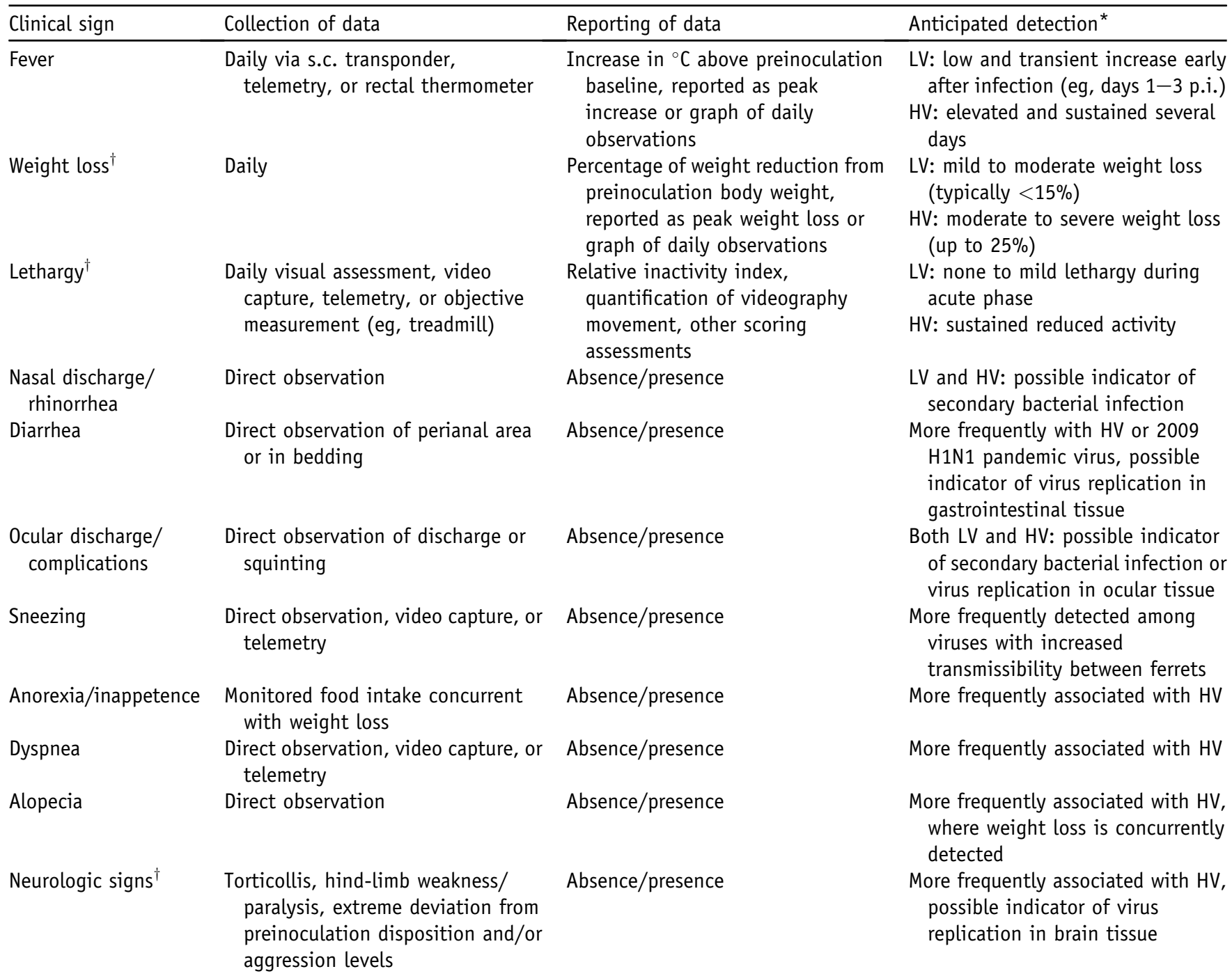

*References supporting this information are found in the text.

TThese parameters are frequently used in criteria for humane euthanasia because of development of severe disease.

LV, viruses possessing low virulence in the ferret model; HV, viruses possessing high virulence in the ferret model; p.i., after infection. 
ocular tissue, can further contribute toward understanding viral replication kinetics and tissue tropism in the ferret. ${ }^{36,38}$ Most influenza viruses exhibiting low mammalian virulence lead to viral replication restricted to the respiratory tract, whereas high virulence influenza viruses can be detected in extrapulmonary tissues, including the brain (Table 1).

Blood collection, typically from the cranial vena cava ${ }^{39,40}$ may be useful in evaluating lymphohematopoietic parameters, tracking migration of peripheral leukocytes, and analyzing host gene expression after influenza virus infection, among other applications. ${ }^{41-44}$ Although viremia is not commonly detected, infectious virus in peripheral blood has been reported after inoculation with select viruses exhibiting high virulence. ${ }^{45}$ Different downstream analyses using blood may require anticoagulants or other treatments, necessitating collection of multiple distinct vials. Ferret blood volume is approximately 5\% of total body weight, and collected volumes (typically 0.5 to $5 \mathrm{~mL}$ ) should not exceed $10 \%$ of total blood volume during one collection or $20 \%$ over a 2 -week period. ${ }^{39}$ Blood may be collected concurrent with other samples during the acute phase of infection while the ferret is sedated; larger volumes are collected via cardiac puncture as a terminal procedure during exsanguination of the ferret immediately before necropsy.

\section{Necropsy}

\section{General Notes}

Necropsy after influenza virus infection can provide a thorough assessment of the scope and severity of pathology and viral load distribution, which can vary greatly depending on the virus strain or subtype. ${ }^{46}$ Necropsy of animals that reach humane end points before study termination (Table 1) provides a greater understanding of disease in severely ill animals. Below, we provide a practical guide to necropsying influenza virus-infected ferrets and describe the utility and application of samples collected for research activities (Table 2). ${ }^{47-66}$

Safety considerations are of paramount importance during all stages of research with influenza virus-infected ferrets. In addition to all institutional animal care and use approvals, respiratory and eye protection should always be a requirement. ${ }^{67,68}$ The use of sharps and chemicals requires training on proper handling and disposal procedures. Manipulation of unsedated ferrets should include the use of leather handling gloves or other protective barriers. Incising thick tissues, such as the skin, and accessing the brain through the bony calvarium (skull) can be challenging and may pose increased risk of injury, especially when compared with other models, such as the mouse or guinea pig, and may warrant incorporating cut-resistant gloves for added protection.

Exsanguination of ferrets immediately before euthanasia can both permit the collection of large quantities of blood and facilitate macroscopic inspection of internal organs during the necropsy. On the basis of American Veterinary Medical Association and institutional guidelines for euthanasia, ${ }^{69}$ chemical euthanasia solutions may be administered via multiple routes, including cardiac puncture or intravenously (eg, cranial vena cava). Confirmation of euthanasia (ie, cessation of breathing and heartbeat) must occur before necropsy procedures begin.

It is important to consider the order of tissue collection before conducting the necropsy to prevent cross contamination between tissues of low versus high viral loads. For example, evaluation and collection of tissues from the abdominal cavity should occur before manipulation of respiratory tract tissues, where viral loads are anticipated to be higher. Sample preservation appropriate for desired downstream applications is a critical component of every necropsy. Tissues collected for titration of infectious virus should be placed on dry ice immediately to retain viral titers. Tissues collected for histopathologic assessment should be no more than $1 \mathrm{~cm}$ in thickness in one plane for proper fixation; $10 \%$ neutral-buffered formalin is the most common fixative used for tissue preservation, with the duration of fixation not to exceed 72 hours to preserve tissue quality for immunohistochemistry. In addition, placement of samples in other appropriate buffers to retain nucleic acid integrity or applications may be required. All buffers and reagents should be prepared and on hand before the necropsy.

\section{Tissue Collection and Use by Organ}

We describe the most frequently examined and sampled tissues in the ferret after influenza virus infection and discuss the myriad information they can provide. Viral quantification (by titration of samples for infectious virus or viral RNA), assessment of inflammation and localization of viral antigen (via histopathology and immunohistochemical assays), and determination of host immune responses (including expression of cytokines and chemokines) represent the most frequently used assays for these samples. Refer to Table 2 throughout this section for additional information. The order of collection, from tissues with the lowest anticipated viral load to the highest, concurrent with decontamination of necropsy instruments with $70 \%$ ethanol between each sample, is critical to minimize the likelihood of cross contamination. The tissue collection order and method presented below represents one approach when collecting samples primarily for determination of infectious viral load; deviation from this order may be warranted, depending on the specific experimental design.

Initially, a ventral midline skin incision extending from the intermandibular space to pubis is made, with reflection of the skin on both sides. A T-shaped incision below the diaphragm through the abdominal musculature (being careful not to puncture the abdominal viscera) exposes the abdominal cavity. 
Table 2 Common Tissues and Samples Collected in Suggested Order during Necropsy of Influenza Virus-Infected Ferrets

\begin{tabular}{|c|c|c|c|c|}
\hline Tissue/sample & Method of collection* & Scope of virus detection ${ }^{\dagger}$ & Additional applications & References \\
\hline Blood & $\begin{array}{l}\text { Exsanguination } \\
\text { preeuthanasia with or } \\
\text { without anticoagulants }\end{array}$ & $\begin{array}{l}\text { Typically only among HV } \\
\text { viruses }\end{array}$ & $\begin{array}{l}\text { Differential cell counts, } \\
\text { serum panels, gene } \\
\text { expression analysis, } \\
\text { analysis of peripheral blood } \\
\text { leukocytes }\end{array}$ & $41-45$ \\
\hline Spleen & $2-3$ small pieces, pooled & $\begin{array}{l}\text { Typically only among HV } \\
\text { viruses }\end{array}$ & $\begin{array}{c}\mathrm{C} / \mathrm{C}^{\ddagger}, \mathrm{H} \& \mathrm{E}^{\S}, \mathrm{IHC} \mathrm{C}^{\Uparrow} \text {, analysis of } \\
\text { tissue leukocytes, ex vivo } \\
\text { splenocyte stimulation }\end{array}$ & $45,47-51$ \\
\hline Intestine & $\begin{array}{l}\text { Pieces from duodenum, } \\
\text { jejunoileum, and } \\
\text { descending colon, typically } \\
\text { pooled }\end{array}$ & $\begin{array}{l}\text { Low titers }{ }^{\|} \text {sporadically } \\
\text { detected with human } \\
\text { viruses, some higher with } \\
\text { avian viruses }\end{array}$ & $\mathrm{C} / \mathrm{C}^{\ddagger}, \mathrm{H} \& \mathrm{E}^{\S}, \mathrm{IHC}$ & $45,47,48$ \\
\hline Kidney & $\begin{array}{l}\text { Small piece from both left } \\
\text { and right kidneys, pooled }\end{array}$ & $\begin{array}{l}\text { Typically only among HV } \\
\text { viruses }\end{array}$ & $C / C^{\ddagger}$ & 48,52 \\
\hline BALF & $\begin{array}{l}\text { Sterile liquid flushed through } \\
\text { trachea and lung tissue and } \\
\text { collected }\end{array}$ & $\begin{array}{l}\text { Most human and zoonotic } \\
\text { influenza viruses }\end{array}$ & $\begin{array}{l}\text { Differential cell counts, } \\
\text { analysis of leukocyte } \\
\text { populations, antibody } \\
\text { responses }\end{array}$ & $49,58-60$ \\
\hline Lung & $\begin{array}{l}\text { Small pieces from each lobe, } \\
\text { may be pooled for a } \\
\text { representative lung sample } \\
\text { or kept separate }\end{array}$ & $\begin{array}{l}\text { Most zoonotic influenza } \\
\text { viruses, some human } \\
\text { viruses }\end{array}$ & $\begin{array}{l}\mathrm{C} / \mathrm{C}^{\ddagger}, \mathrm{H} \& \mathrm{E}^{\S}, \mathrm{IHC} \mathrm{C}^{\mp} \text {, deep } \\
\text { sequencing, live imaging }\end{array}$ & $45,47,48,56,61,62$ \\
\hline $\begin{array}{l}\text { Brain } \\
\qquad \text { (olfactory bulb) }\end{array}$ & $\begin{array}{l}\text { Entire tissue, left and right } \\
\text { bulbs may be pooled or not }\end{array}$ & $\begin{array}{l}\text { Lower titers among most } \\
\text { zoonotic viruses, some } \\
\text { seasonal viruses; higher } \\
\text { titers among HPAI }\end{array}$ & $\mathrm{C} / \mathrm{C}^{\ddagger}, \mathrm{H} \& \mathrm{E}^{\S}, \mathrm{IHC}$ & $45,47,48,51,52,57$ \\
\hline Nasal turbinates & $\begin{array}{l}\text { Mechanical disruption of } \\
\text { tissue with forceps; } \\
\text { removal and collection of } \\
\text { entire accessible tissue }\end{array}$ & $\begin{array}{l}\text { Most human and zoonotic } \\
\text { viruses, with few } \\
\text { exceptions }\end{array}$ & $\begin{array}{l}\mathrm{C} / \mathrm{C}^{\ddagger}, \mathrm{H} \& \mathrm{E}^{\S}, \mathrm{IHC} \mathrm{C}^{\Phi} \text {, ex vivo cell } \\
\text { culture, deep sequencing }\end{array}$ & $45,47,48,56,61,65,66$ \\
\hline
\end{tabular}

${ }^{*}$ Method of collection describes use for viral titration. Remainder or representative sections of each tissue may be placed in formalin after sample collection if desired.

'Infectious viral titers are typically reported per gram of tissue, with the exception of blood, BALF, eye, conjunctiva, and nasal turbinates, which are frequently reported per $\mathrm{mL}$ of sample.

${ }^{\ddagger}$ C/C, as typically determined by RT-PCR because of a lack of ferret-specific commercially available kits to measure secreted protein by enzyme-linked immunosorbent assay or other methods.

${ }^{\S}$ Histopathologic evaluation after H\&E staining.

IHC, inclusive of detection of viral antigen (typically NP) and other assays.

"Low titers, generally $\leq 10^{3}$ infectious units.

BALF, bronchoalveolar lavage fluid; C/C, cytokine and chemokine production; H\&E, hematoxylin-eosin; HPAI, highly pathogenic avian influenza; HV, viruses that possess high virulence in the ferret model; IHC, immunohistochemistry; NP, nucleoprotein. 


\section{Spleen}

The ferret spleen is a crescent-shaped, brown to maroon organ located in the left cranial quadrant of the abdomen, caudal to the liver and along the greater curvature of the stomach, attached by the gastrosplenic ligament (Figure 1A). Remove the spleen by severing the gastrosplenic ligament, collect small pieces from different regions, and pool for virus titration. Additional segments of the spleen may be homogenized to purify splenocytes; specimens can also be collected in formalin for histology. ${ }^{50}$

Viruses exhibiting high virulence in ferrets are frequently recovered from the spleen. ${ }^{45,52}$ Virus-specific changes are not commonly noted in the spleen, but splenomegaly or increased cellularity from splenic suspensions has been noted after influenza virus infection. ${ }^{49}$ Viral antigen detection and significant cytokine and chemokine responses have been reported in the spleen after infection with highly virulent influenza viruses. ${ }^{48}$ Given the importance of the spleen in both humoral and cell-mediated immune responses, isolated splenocytes from virus-infected ferrets can be used to assess cellular immune responses either immediately or for subsequent stimulation ex vivo to evaluate cross-reactive immune responses. $^{49,50}$

\section{Kidneys}

The kidneys are retroperitoneal in the sublumbar region of the abdominal cavity on either side of the vertebral column, dorsally apposed to the subaxial muscles and ventrally enveloped by a thin, variably fatty peritoneum (Figure 1A). Small pieces are cut from each kidney and pooled for virus titration. Similar to the spleen, infectious virus and modulation of proinflammatory cytokines and chemokines are typically only detected in the kidneys after inoculation with highly virulent strains of influenza virus. ${ }^{48,52}$ Specific virusrelated gross pathology is not generally observed. Despite the sporadic nature of influenza virus detection in kidney tissue, gross and histopathologic examination of kidneys can be conducted to evaluate for other underlying renal disease that can contribute to disease progression. Furthermore, this information may be useful in interpreting clinical blood chemistry panels that include indicators of kidney function. ${ }^{43}$ Adrenal glands located at the craniomedial poles
A
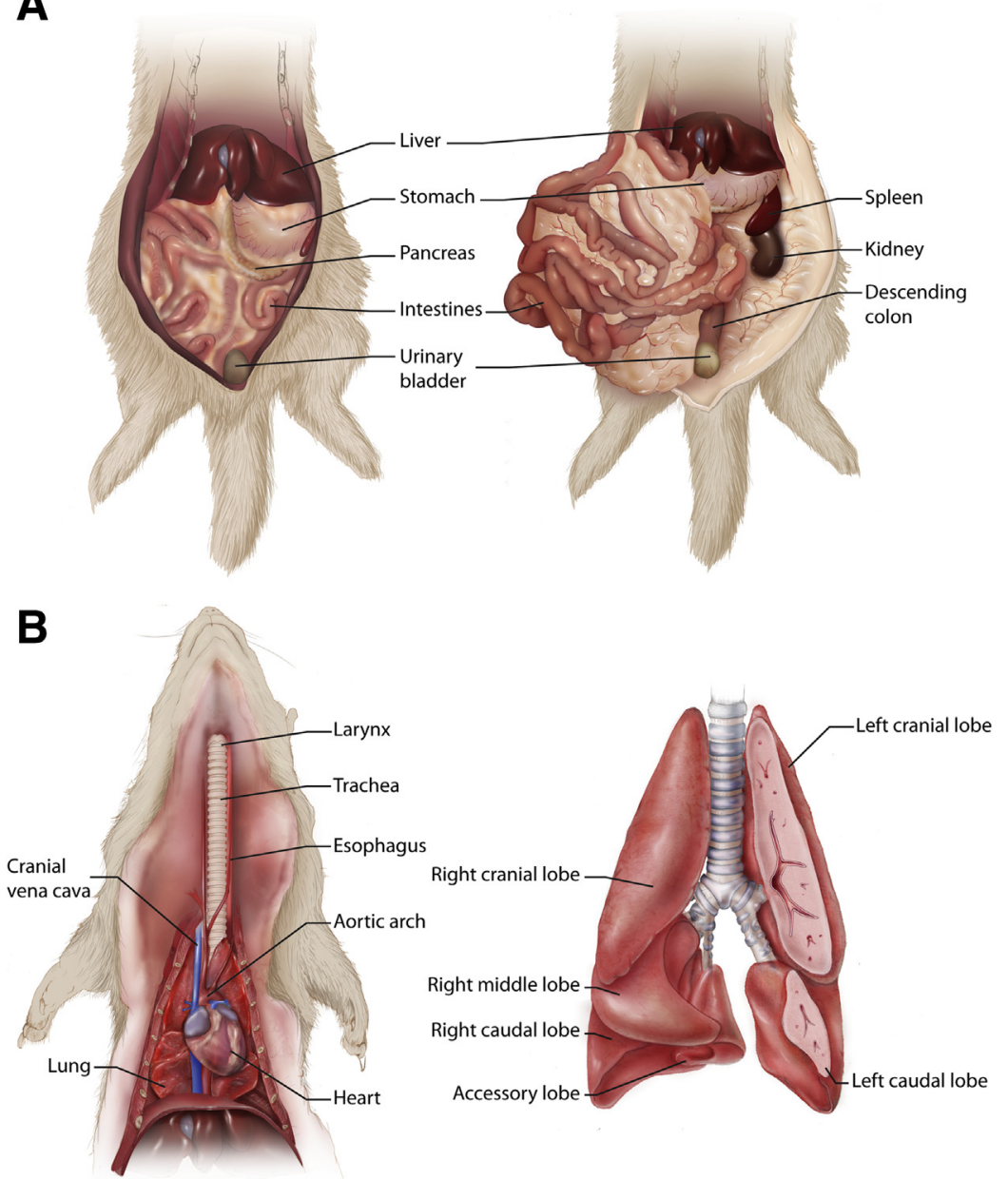

Figure 1 A: Abdominal organs in the ferret. Left panel: Visible organs on first entering the abdominal cavity include the liver, gastrointestinal (GI) tract, spleen, and urinary bladder. The pancreas lies closely adjacent to the pylorus and may not be readily visible without further handling of the GI tract. Right panel: With the GI tract moved to the side or lifted en bloc, the kidneys are found within the retroperitoneal space, along the dorsum, often embedded in adipose tissue. Differentiation of the intestinal segments may require removal of the GI tract en bloc, followed by separation of the loops for dissection and identification. The urinary bladder lies ventral to the rectum. B: Neck (cervical) and thoracic organs in the ferret. Left panel: Ventral midline incision through the soft tissues of the neck reveals the larynx, esophagus, and trachea (as well as thyroid gland and major vessels, not shown). The esophagus lies immediately dorsal to the trachea cranially and shifts toward the left as it courses caudally. The larynx is located at the cranial most end of the trachea. The caudal trachea bifurcates at the hilus of the lung, forming the mainstem bronchi as they enter the lungs. Removal of the ventral aspect of the ribcage reveals the lungs and heart. Right panel: The lungs in the ferret are composed of the cranial and caudal lobes on the left and cranial, middle, accessory, and caudal lobes on the right. Also shown are cut surfaces of the left lung lobes, revealing the spongy parenchyma and branching bronchi and vasculature. The tracheobronchial lymph nodes (not shown) are located at the hilus. 
of the kidneys may also be sampled; viral titers have been reported in this tissue. ${ }^{70}$

\section{Intestine and Pancreas}

Influenza virus may be sporadically detected in gastrointestinal samples (either in tissue specimens or rectal swabs), so intestinal tissue is routinely collected. The ferret alimentary tract consists of the esophagus, a simple monogastric stomach, the small intestines (including duodenum), jejunoileum, and the large intestines (Figure 1A). Small pieces of tissue that are free of digestive matter from the duodenum, jejunoileum, and descending colon (proximal to the rectum) are most frequently sampled; tissues may be pooled for a representative intestinal sample or tested individually. ${ }^{71,72}$ Avoid scraping the mucosa when removing digesta to prevent loss of tissue during collection; alternatively, rinsing the specimen with sterile saline can be used to remove digesta. Noting the presence or absence of food in the stomach can inform assessments of anorexia and weight loss after infection, although stomach tissue is not frequently collected.

Selected viruses that have been associated with gastrointestinal distress and vomiting in humans have been recovered at higher rates from intestinal tissue of infected ferrets $^{72}$; however, gross pathology (observation of necrotic tissue, hematomas, or hemorrhages in tissue or mesentery) is typically only present in animals infected with viruses exhibiting high virulence in ferrets. Histopathologic and immunohistochemical examination is more commonly performed on tissue from the jejunoileum, but necrosis and viral antigen have been reported in both small and large intestinal tissue from virus-infected ferrets. ${ }^{71,73,74}$ Virus has also been detected in the mesenteric lymph nodes after both intranasal and intragastric virus inoculation; changes in leukocyte subsets have been reported in this tissue. ${ }^{49,73}$ Although the esophagus is not frequently collected, standard intranasal inoculation may lead to deposition of influenza virus in the esophagus because of swallowing of inoculum, and infectious virus has been detected in this tissue. $^{75,76}$

The pancreas is an elongated, pale tan, glandular organ, with the body of the pancreas located closely adjacent to the pylorus and extension of the left and right limbs toward the stomach and duodenum, respectively (Figure 1B). Although not routinely sampled, necrosis of the pancreatic duct epithelium with concurrent detection of viral antigen has been reported after infection with highly virulent H5N1 viruses, with changes in viral titers and cytokine expression. . $^{51,52,57,71}$

\section{Liver and Gallbladder}

The ferret liver, located caudal to the diaphragm and cranial to the stomach (Figure 1A), consists of six lobes (left and right lateral, left and right medial, quadrate, and caudate) and is uniformly dark red in appearance. Discoloration or petechiation in one or multiple lobes may be observed. Small pieces of liver are collected from multiple lobes and pooled as a representative sample for titration. If necessary, entire lobes may be removed if pathology is observed, by loafing and placing sections in fixative for subsequent histopathologic analysis, which may be useful in interpreting clinical blood chemistry panels that include indicators of liver function. ${ }^{77}$ Viral titers in the liver are generally low among highly virulent influenza viruses ${ }^{45,78}$ and may or may not be associated with viremia, but have been reported after multiple inoculation routes. ${ }^{71,73}$ Viral antigen has been detected in hepatocytes, and altered cytokine expression has been reported in liver samples from influenza virus-infected ferrets. ${ }^{48,52,57}$

The gallbladder is a single-lobed, brownish green sac located between the quadrate and right medial lobes of the liver. The bile duct opens into the lumen of the duodenum via a major duodenal papilla, along with the pancreatic duct. Although not commonly sampled after influenza virus infection, bile duct necrosis and detection of viral antigen in bile duct epithelia have been reported after infection with virulent influenza viruses. ${ }^{71}$ Visual examination for lesions at necropsy is prudent, as ferrets exhibiting severe disease may possess discolored and/or distended gallbladders in conjunction with severe, multiorgan involvement. Testing the patency of the common bile duct is performed by manually expressing the gallbladder and monitoring excretion into the duodenal lumen, but care must be taken not to allow bile, which is highly caustic, to contaminate other tissues that have not yet been sampled.

\section{Trachea}

Collection and titration of tracheal tissue may provide useful information regarding the scope of virus replication throughout the ferret respiratory tract, especially when interpreting viral load in nasal wash specimens, which can be inclusive of virus released from multiple sites beyond the nasal passage. ${ }^{19}$ Tracheal samples collected just distal to the larynx (cranial region) may possess differential distributions of sialic acid moieties and levels of infectious virus compared with samples collected proximal to the mainstem bronchi (caudal region). ${ }^{3,19}$ As such, uniformity in collection method between animals within a group, or between different groups in a study, is essential.

Removal of the ribcage by transecting the ribs at the costochondral junctions bilaterally and cutting away the pleural attachments will reveal the thoracic cavity (Figure 1B). The trachea may be sampled before or after removal of the lower respiratory tract en bloc by bisecting at the mid to distal trachea; care should be taken to avoid cross contamination of this tissue. Pieces of the trachea (1 to 2 $\mathrm{cm}$ ) are collected using scissors for virus titration, and may be pooled or kept separate. Avoid the esophagus during manipulation of the trachea, and remove visible connective tissue attached to the surface of the trachea (Figure 1B). Alternatively, the trachea may be removed as part of the pluck. The pluck consists of the tongue, tonsils, larynx, thyroids, trachea, lungs, and heart removed en bloc; with the ribcage removed, this is achieved via a ventral approach 
through the mandible to dissect out the tongue and subsequent detachment of the entire tongue-to-lung segment as one unit, bearing in mind that hyoid bones may need to be transected with rongeurs to release the tissue cranially.

It is beneficial to leave a short section of the trachea attached to the bronchi to facilitate orientation of this tissue for histopathologic purposes and for intra-alveolar perfusion of lung tissue with formalin once all samples from respiratory tissues have been collected. Histologically, mild to moderate tracheitis has been reported. ${ }^{79}$ Formalin-fixed tracheal tissue can also be used for subsequent immunohistochemistry applications. ${ }^{52}$ Elevated levels of proinflammatory cytokines and chemokines have been reported in tracheal tissue after in vivo ferret infection or after ex vivo infection of differentiated ferret primary tracheal epithelial cells. ${ }^{53,54}$ Infectious virus has also been recovered from tracheobronchial lymph nodes, ${ }^{73}$ which can be found adjacent to the trachea and near its bifurcation into the mainstem bronchi.

\section{Heart}

Viral titers have been infrequently reported in the heart for select H7N9 and H5N1 viruses, also associated with viremia. Immunohistochemical assays of heart tissue have been negative, with the exception of rare reports of viral antigen detection. ${ }^{47,57,78,79}$ One to two small pieces of myocardium are typically sufficient for virus titration. Avoid cross contamination of this tissue with neighboring lung tissue, which may contain higher viral loads (Figure 1B). Proinflammatory cytokines and chemokines have been reported in heart tissue infected by influenza viruses; gross pathology is not typically observed in the ferret heart. ${ }^{48,52}$

\section{Bronchoalveolar Lavage Fluid}

Just as collection and titration of nasal wash specimens may inform and support data collected from other upper respiratory tract tissues sampled during necropsy, collection and titration of wash specimens from the lower respiratory tract may be similarly beneficial. Bronchoalveolar lavage fluid may be collected longitudinally from anesthetized ferrets, by using an endotracheal tube to retrieve aspirate, ${ }^{60}$ but is most commonly collected postmortem by flushing the trachea and lungs with sterile fluid and collecting the aspirate. ${ }^{58}$ Bronchoalveolar lavage fluid may be titered for the presence of infectious virus and is often concurrently evaluated to measure cellular immune responses or tested for the presence of antibodies by enzyme-linked immunosorbent assay. ${ }^{49,58-60}$ Ferret alveolar macrophages, collected by this method and cultured ex vivo, have been shown to support influenza virus replication, as indicated by detection of infectious virus by titration and viral antigen via immunofluorescence staining. ${ }^{80}$

\section{Lung}

The ferret lung consists of six lobes: left cranial and caudal, right cranial, middle, and caudal, and accessory (Figure 1B).
Ferret lungs are generally uniformly pale pink and spongy, and variations in color and consistency are not uncommon in uninfected lungs. Collection of small pieces from each lobe $(\leq 1 \mathrm{~g}$ in total) are pooled for titration or other downstream applications. Lung specimens may also be sampled and analyzed separately to investigate localization of virus. The lungs can then be fixed for histochemical evaluation by perfusing formalin into the lungs so the retention of expanded alveoli is achieved. A $1-\mathrm{mL}$ syringe may be used to deliver formalin to the lungs via the trachea or large bronchi. Considering the importance of studying lung tissue and function during influenza virus infection, there are a large range of downstream applications and analyses frequently performed on this tissue.

Like the trachea, uniformity in collection of lung samples among groups is essential, as viral loads may differ between lobes of the lung, as well as spatially within each lobe. ${ }^{19}$ For example, collection of samples at the perihilar regions of the lung may yield more reproducible and detectable viral titers than samples collected toward the periphery of each lobe. Infectious virus titers and viral antigen have been shown to vary between the bronchus, bronchioles, and alveoli, depending on the virus inoculum and the day postinfection sampling occurred. $^{81}$ Similarly, induction of proinflammatory cytokines and chemokines after infection may vary between different compartments of the ferret lung, ${ }^{82}$ necessitating uniformity in collection and reporting of the samples being examined. Live imaging of neutrophil levels in the ferret lung after influenza virus infection further supports regional differences in cellular infiltration, both globally and locally within this tissue at different time points after inoculation. ${ }^{62}$ The use of next-generation sequencing has improved our understanding of the variance in subsets of viral populations throughout the ferret respiratory tract, highlighting the contribution of virus replication at different anatomic sites toward virus pathogenicity and transmissibility in this model. ${ }^{56,83}$

Gross lesions are frequently observed in lung tissue during acute influenza virus infection and warrant careful evaluation. However, an in-depth review of the lesions seen with influenza viruses in the ferret model is outside the scope of this review. Generally, gross pathology can vary from mild suspected pulmonary consolidation ( $\leq 10 \%$ of the lung) with viruses of low virulence to multifocal or diffuse consolidation and/or discoloration often associated with highly pathogenic viruses. The spectrum of histopathologic lesions of influenza viruses in the ferret is highly dependent on the virus strain. In general, both low- and high-virulence influenza A viruses infect the airway epithelium from the nasal passages to the bronchioles. Such lesions include necrotizing rhinitis, with or without tracheitis, bronchitis, and bronchiolitis. Highly virulent influenza A viruses typically exhibit injury of airway epithelium that, dependent on the virus strain, can extend into the alveolar septae/interstitium and/or extrapulmonary tissues. For example, neutrophilic and mononuclear inflammation can be observed surrounding bronchioles and spreading 
into the alveolar interstitium and spaces, accompanied by intra-alveolar edema and hemorrhage. ${ }^{46,71,72,79,84}$

The draining lymph nodes (hilar and mediastinal lymph nodes) may be difficult to locate in uninfected ferrets but can be informative when assessing inflammatory responses during the acute phase of infection. Titration and immunohistochemistry have identified the presence of influenza virus in the ferret hilar lymph nodes, ${ }^{85}$ and leukocyte populations have been analyzed in mediastinal lymph nodes. ${ }^{49}$

\section{Eye and Conjunctiva}

Influenza viruses are a principal respiratory pathogen in humans; ocular tissue represents both a potential site of influenza virus replication and a potential anatomic conduit to establish a productive respiratory infection in mammals. ${ }^{86}$ Ferrets have been identified as a suitable experimental model for research pertaining to the ocular system, ${ }^{87-89}$ and infectious virus has been recovered from eye swabs and washes in ferrets. ${ }^{38}$ Conjunctival tissue from the ferret may be obtained by using a scalpel to remove the tissue surrounding the opening of each eye (approximately $1-\mathrm{cm}$ radius from the eyelid). The globe (eyeball) may be removed by proptosing it from the orbit and using scissors to transect the optic nerve and surrounding retrobulbar soft tissues (Figure 2). Conjunctival and eye tissue may be differentiated as right or left or pooled for collective conjunctival and eye samples.

Eyes and conjunctival tissue are infrequently sampled during necropsy of influenza virus-infected ferrets, but influenza viral antigen has been reported in the eyes and conjunctival tissue after ocular inoculation, and respiratory or ocular exposures to influenza virus. ${ }^{38,90}$ Ferrets do not routinely develop conjunctivitis after either intranasal or ocular inoculation with influenza virus. ${ }^{63}$ Proinflammatory cytokines and chemokines have been detected during the acute phase of infection in these samples. ${ }^{53}$ To facilitate complete fixation of the relatively large globe, injection of formalin into the vitreous chamber through the sclera at the

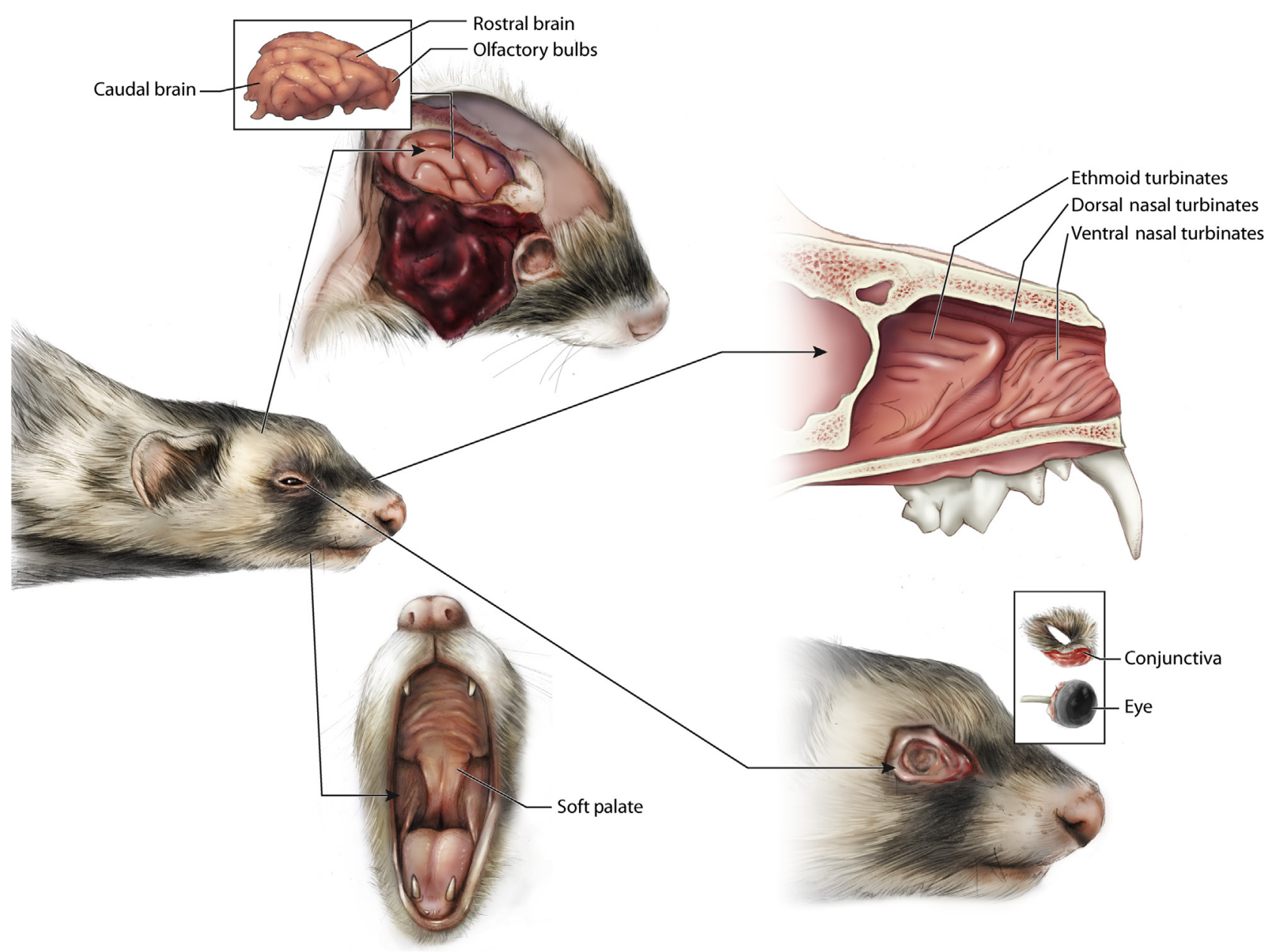

Figure 2 Tissues collected from the head include the conjunctiva and eye, soft palate, nasal turbinates, and brain. The method of brain removal shown is via a large opening along one side of the skull to allow lateral extraction of the entire brain. A sagittal section through the muzzle is shown to indicate the location of the nasal turbinates, which can be dislodged and removed using forceps via the nasal cavity. The conjunctiva is excised using a scalpel, and the eye is removed by proptosing the globe, detaching the associated connective tissue and muscle, and transecting the optic nerve. The soft palate is located deep in the back of the mouth and may require removal of the mandible for easier access. 
limbus may be performed to help preserve the delicate ocular anatomy and inactivate any virus that may be present.

\section{Brain and Central Nervous System}

Although influenza viruses are not typically neurotropic, influenza viruses exhibiting high virulence in ferrets may spread to the central nervous system via the olfactory and cranial nerve pathways, as well as via the inner ear and vestibulocochlear nerve..$^{51,64,91}$ Depending on the scope of the study, various methods for exposure of the brain may be required. Traditionally, removal of the entire calvarium using rongeurs can allow the whole brain to be obtained intact for subsequent sampling of specific areas of interest. Alternatively, removal of half of the skull using rongeurs can allow for lateral extraction of the brain, starting at the orbit to generate the opening (Figure 2). Brain tissue should be handled and sampled in a caudal to rostral direction as higher titers of virus are found in the more rostral regions of the brain, but the caudal and rostral cerebrum may be pooled if this is not a concern. ${ }^{92}$ The olfactory bulbs, located rostral to the cerebrum, can be removed from the calvarium while still attached to the cerebrum or separately. Infectious virus may be detected in olfactory bulb tissue in the absence of virus detection in the cerebrum; this is often attributed to the close proximity of olfactory bulbs to the nasal passages, where the highest viral load is typically detected in an infected ferret. Therefore, olfactory bulbs should be manipulated last as this region of the brain typically holds the greatest amount of virus from this organ.

Viral titers and viral antigen have been occasionally reported in the ferret cerebellum, brainstem, spinal cord, and cerebrospinal fluid after infection with highly virulent viruses, concurrent with histologic evidence of inflammation within these sites. ${ }^{57,66,70}$ Detection of viral antigen has also been reported, albeit sporadically, in meningeal cells surrounding the cerebrum, cerebellum, and spinal cord, ependymal cells lining the ventricles, and astrocytes. ${ }^{51,70,91}$ Inflammation seen by histopathology is not uncommon after ferret inoculation with highly virulent viruses. ${ }^{45}$ Like the cerebrum, cytokine and chemokines can be measured in this tissue. ${ }^{48,52}$ Remaining tissue is formalin fixed for histopathologic analysis and immunohistochemical staining. ${ }^{57,64}$

\section{Nasal Turbinates and Nasopharynx}

Nasal turbinates can be accessed by using a scalpel to excise the nose and an approximately $1-\mathrm{cm}$ segment of the muzzle, revealing a cross-section of the nasal cavity with the right and left chambers bisected by the nasal septum (Figure 2). Forceps are then used to dislodge and forcibly extract fragments of nasal turbinate tissue from both chambers. Because of the small total sample collected, nasal turbinates are collected in their entirety for subsequent processing, or the sample can be split to preserve tissue for concurrent immunohistochemistry assays. ${ }^{57}$ Alternatively, removal of the overlying nasal bones can be performed using rongeurs to expose the entire nasal canal up to the ethmoid turbinates, allowing more precise anatomic localization for tissue sampling. Histopathologic and/or immunohistochemical examination of the entire nasal turbinate tissue can also be performed by fixation of the intact calvarium, after decalcification and serial sectioning through the entire nasal region.

Nasal turbinates typically contain high viral loads in ferrets infected with influenza virus, and, like the trachea, they provide important supporting information to interpret titers from nasal wash or swab specimens. Ex vivo infection of differentiated ferret nasal turbinate epithelial cells further supports the capacity for high titer virus replication in this tissue. ${ }^{66,93}$ Expression of proinflammatory cytokines and chemokines may be measured in homogenized samples of this tissue. ${ }^{61}$ Furthermore, deep sequencing of viral quasispecies has been performed in this sample, ${ }^{56}$ which can provide critical information when examining the emergence of viruses bearing mutations that facilitate mammalian adaptation. ${ }^{94}$

The soft palate, located on the caudoventral aspect of the nasopharynx (Figure 2), bears permissive receptors for influenza virus and has been recently identified as an important tissue for host adaptation of influenza virus. ${ }^{4,56}$ Visualization of the ventral aspect of the upper palate can be achieved by removal of the soft tissues between the mandibular rami, including the tongue, or via dislocation of the entire mandible at the temporomandibular joints. A scalpel or scissors can then be used to excise the soft tissue caudal to the hard palate. Soft palate tissue may support replication of high levels of virus; furthermore, inflammation of the soft palate after influenza virus infection can be observed by histopathology and immunohistochemistry. ${ }^{56,95}$ The tonsils are not routinely sampled, but have been reported to exhibit changes in immunostaining patterns after influenza virus infection..$^{70,73}$ This tissue can be obtained at the time of soft palate excision. Leukocyte populations have been occasionally assessed after infection in medial retropharyngeal lymph nodes. ${ }^{49}$

\section{Additional Considerations}

The procedures described herein apply primarily to scheduled necropsies conducted during the acute phase of infection. Necropsies performed later in infection (eg, concurrent with a ferret reaching humane end points and euthanized because of development of severe illness) may present with differing viral replication kinetics than those performed early during infection, as viral loads in specific tissues may peak at different times after inoculation. Similarly, histopathologic findings and densities of immune cell populations may differ greatly between necropsies of ferrets conducted during acute or convalescent phases of infection. Many of the downstream applications described in Table 2 require complete virus inactivation before subsequent sample manipulation; validation of these inactivation procedures represents a necessary safety measure.

Necropsies should be conducted immediately after euthanasia when possible, as autolysis can drastically affect virus 
titers and hinder histopathologic examination. When unavoidable, refrigeration can help reduce the severity of autolysis and preserve cellular quality and tissue architecture. Freezing of the carcass is discouraged because of introduction of freeze artifacts that can affect interpretation of any gross findings and distort histology. It is important to consistently perform a comprehensive necropsy of each animal to evaluate for evidence of other concurrent disease(s) that may confound results related to influenza studies. Some common findings in the ferret include, but are not limited to, adrenal neoplasms, lymphoma, extramedullary hematopoiesis in the spleen, splenic lymphoma, insulinoma, and Helicobacter gastritis. ${ }^{40}$

\section{Summary}

Given the importance of both kinetic and static assessments of viral load, experimentation with influenza virus-infected ferrets typically includes a group of animals followed throughout the acute phase of infection and a group of animals scheduled for necropsy at a time point during the acute phase of infection. Each experimental approach permits the collection of valuable data that, as a whole, can provide complementary insights into influenza virus pathogenicity. The diversity of post-collection applications and analyses available in the laboratory offers a potential wealth of information to improve our understanding of influenza virus virulence and pathogenesis; it is incumbent on researchers to gain as much knowledge and address as many outstanding questions as possible when working in vivo to minimize the need for repeated experimentation that would result in the use of additional animals. By presenting the full scope of parameters examined from each major tissue and organ system after influenza virus infection in ferrets, laboratory and veterinary staff can make the most informed decisions for a comprehensive study of these animals in this setting.

Study of influenza virus-infected ferrets represents an invaluable resource in understanding the virulence of influenza viruses in mammals, but data from these experiments are only one of many laboratory assessments that contribute to our understanding of mammalian pathogenicity. In parallel with other studies of virus, host, and environmental properties, results from the ferret model can guide public health decision-making practices ${ }^{9,10}$ and advance our understanding of the properties that contribute to influenza virus mammalian virulence, tropism, and transmissibility. Fully appreciating the current scope of information gained by the study of influenza virus-infected ferrets will better enable both veterinary staff and laboratorians to design, conduct, and interpret these studies as comprehensively as possible.

\section{Acknowledgments}

We thank Nicole Brock and Wun-Ju Shieh for critical review of the manuscript.

\section{References}

1. Enkirch T, von Messling V: Ferret models of viral pathogenesis. Virology 2015, 479-480:259-270

2. Maher JA, DeStefano J: The ferret: an animal model to study influenza virus. Lab Anim 2004, 33:50-53

3. Jayaraman A, Chandrasekaran A, Viswanathan K, Raman R, Fox JG, Sasisekharan R: Decoding the distribution of glycan receptors for human-adapted influenza A viruses in ferret respiratory tract. PLoS One 2012, 7:e27517

4. Jia N, Barclay WS, Roberts K, Yen HL, Chan RW, Lam AK, Air G, Peiris JS, Dell A, Nicholls JM, Haslam SM: Glycomic characterization of respiratory tract tissues of ferrets: implications for its use in influenza virus infection studies. J Biol Chem 2014, 289: 28489-28504

5. Ng PS, Bohm R, Hartley-Tassell LE, Steen JA, Wang H, Lukowski SW, Hawthorne PL, Trezise AE, Coloe PJ, Grimmond SM, Haselhorst T, von Itzstein M, Paton AW, Paton JC, Jennings MP: Ferrets exclusively synthesize Neu5Ac and express naturally humanized influenza A virus receptors. Nat Commun 2014, 5:5750

6. van Riel D, Munster VJ, de Wit E, Rimmelzwaan GF, Fouchier RA, Osterhaus AD, Kuiken T: Human and avian influenza viruses target different cells in the lower respiratory tract of humans and other mammals. Am J Pathol 2007, 171:1215-1223

7. Reuman PD, Keely S, Schiff GM: Assessment of signs of influenza illness in the ferret model. J Virol Methods 1989, 24:27-34

8. Belser JA, Katz JM, Tumpey TM: The ferret as a model organism to study influenza A virus infection. Dis Model Mech 2011, 4:575-579

9. Cox NJ, Trock SC, Burke SA: Pandemic preparedness and the Influenza Risk Assessment Tool (IRAT). Curr Top Microbiol Immunol 2014, 385:119-136

10. World Health Organization. Tool for influenza pandemic risk assessment (TIPRA). Geneva: WHO, 2016. Available at https://www.who. int/influenza/publications/TIPRA_manual_v1/en (accessed November $16,2019)$

11. Belser JA, Johnson A, Pulit-Penaloza JA, Pappas C, Pearce MB, Tzeng WP, Hossain MJ, Ridenour C, Wang L, Chen LM, Wentworth DE, Katz JM, Maines TR, Tumpey TM: Pathogenicity testing of influenza candidate vaccine viruses in the ferret model. Virology 2017, 511:135-141

12. Margine I, Krammer F: Animal models for influenza viruses: implications for universal vaccine development. Pathogens 2014, 3: 845-874

13. Oh DY, Hurt AC: Using the ferret as an animal model for investigating influenza antiviral effectiveness. Front Microbiol 2016, 7:80

14. van der Vries E, Stittelaar KJ, van Amerongen G, Veldhuis Kroeze EJ, de Waal L, Fraaij PL, Meesters RJ, Luider TM, van der Nagel B, Koch B, Vulto AG, Schutten M, Osterhaus AD: Prolonged influenza virus shedding and emergence of antiviral resistance in immunocompromised patients and ferrets. PLoS Pathog 2013, 9: e1003343

15. Paquette SG, Banner D, Huang SS, Almansa R, Leon A, Xu L, Bartoszko J, Kelvin DJ, Kelvin AA: Influenza transmission in the mother-infant dyad leads to severe disease, mammary gland infection, and pathogenesis by regulating host responses. PLoS Pathog 2015, $11: \mathrm{e} 1005173$

16. Kim HM, Kang YM, Ku KB, Park EH, Yum J, Kim JC, Jin SY, Lee JS, Kim HS, Seo SH: The severe pathogenicity of alveolar macrophage-depleted ferrets infected with 2009 pandemic H1N1 influenza virus. Virology 2013, 444:394-403

17. Roosenhoff R, van der Vries E, van der Linden A, van Amerongen G, Stittelaar KJ, Smits SL, Schutten M, Fouchier RAM: Influenza $\mathrm{A} / \mathrm{H} 3 \mathrm{~N} 2$ virus infection in immunocompromised ferrets and emergence of antiviral resistance. PLoS One 2018, 13:e0200849

18. Peng X, Alfoldi J, Gori K, Eisfeld AJ, Tyler SR, Tisoncik-Go J, et al: The draft genome sequence of the ferret (Mustela putorius furo) 
facilitates study of human respiratory disease. Nat Biotechnol 2014, 32:1250-1255

19. Belser JA, Eckert AM, Tumpey TM, Maines TR: Complexities in ferret influenza virus pathogenesis and transmission models. Microbiol Mol Biol Rev 2016, 80:733-744

20. Belser JA, Brock N, Sun X, Jones J, Zanders N, Hodges E, PulitPenaloza JA, Wentworth D, Tumpey TM, Davis T, Maines TR: Mammalian pathogenesis and transmission of avian influenza A(H7N9) viruses, Tennessee, USA, 2017. Emerg Infect Dis 2018, 24: $149-152$

21. van de Sandt CE, Bodewes R, Rimmelzwaan GF, de Vries RD: Influenza B viruses: not to be discounted. Future Microbiol 2015, 10: $1447-1465$

22. Huang SS, Banner D, Paquette SG, Leon AJ, Kelvin AA, Kelvin DJ: Pathogenic influenza B virus in the ferret model establishes lower respiratory tract infection. J Gen Virol 2014, 95:2127-2139

23. Matsuzaki Y, Katsushima N, Nagai Y, Shoji M, Itagaki T, Sakamoto M, Kitaoka S, Mizuta K, Nishimura H: Clinical features of influenza C virus infection in children. J Infect Dis 2006, 193: $1229-1235$

24. Ferguson L, Olivier AK, Genova S, Epperson WB, Smith DR, Schneider L, Barton K, McCuan K, Webby RJ, Wan XF: Pathogenesis of influenza D virus in cattle. J Virol 2016, 90:5636-5642

25. Webster RG, Sharp GB, Claas EC: Interspecies transmission of influenza viruses. Am J Respir Crit Care Med 1995, 152:S25-S30

26. Fouchier RA, Munster V, Wallensten A, Bestebroer TM, Herfst S, Smith D, Rimmelzwaan GF, Olsen B, Osterhaus AD: Characterization of a novel influenza A virus hemagglutinin subtype (H16) obtained from black-headed gulls. J Virol 2005, 79:2814-2822

27. Swayne DE: Animal Influenza, ed 2. Ames, IA: Wiley-Blackwell, 2016

28. Karlsson EA, Meliopoulos VA, Savage C, Livingston B, Mehle A, Schultz-Cherry S: Visualizing real-time influenza virus infection, transmission and protection in ferrets. Nat Commun 2015, 6:6378

29. Richard M, Herfst S, Tao H, Jacobs NT, Lowen AC: Influenza A virus reassortment is limited by anatomical compartmentalization following coinfection via distinct routes. J Virol 2018, 92. e02063-17

30. OIE: Manual of Diagnostic Tests and Vaccines for Terrestrial Animals, ed 8. Paris, France: The World Organisation for Animal Health, 2018

31. Pulit-Penaloza JA, Sun X, Creager HM, Zeng H, Belser JA, Maines TR, Tumpey TM: Pathogenesis and transmission of novel highly pathogenic avian influenza $\mathrm{H} 5 \mathrm{~N} 2$ and $\mathrm{H} 5 \mathrm{~N} 8$ viruses in ferrets and mice. J Virol 2015, 89:10286-10293

32. Belser JA, Gustin KM, Pearce MB, Maines TR, Zeng H, Pappas C, Sun X, Carney PJ, Villanueva JM, Stevens J, Katz JM, Tumpey TM: Pathogenesis and transmission of avian influenza A (H7N9) virus in ferrets and mice. Nature 2013, 501:556-559

33. Belser JA, Creager HM, Sun X, Gustin KM, Jones T, Shieh WJ, Maines TR, Tumpey TM: Mammalian pathogenesis and transmission of H7N9 influenza viruses from three waves, 2013-2015. J Virol 2016, 90:4647-4657

34. Van Hoeven N, Belser JA, Szretter KJ, Zeng H, Staeheli P, Swayne DE, Katz JM, Tumpey TM: Pathogenesis of 1918 pandemic and $\mathrm{H} 5 \mathrm{~N} 1$ influenza virus infections in a guinea pig model: antiviral potential of exogenous alpha interferon to reduce virus shedding. J Virol 2009, 83:2851-2861

35. Inagaki K, Song MS, Crumpton JC, DeBeauchamp J, Jeevan T, Tuomanen EI, Webby RJ, Hakim H: Correlation between the interval of influenza virus infectivity and results of diagnostic assays in a ferret model. J Infect Dis 2016, 213:407-410

36. Meunier I, Embury-Hyatt C, Stebner S, Gray M, Bastien N, Li Y, Plummer F, Kobinger GP, von Messling V: Virulence differences of closely related pandemic $2009 \mathrm{H} 1 \mathrm{~N} 1$ isolates correlate with increased inflammatory responses in ferrets. Virology 2012, 422:125-131

37. Herlocher ML, Elias S, Truscon R, Harrison S, Mindell D, Simon C, Monto AS: Ferrets as a transmission model for influenza: sequence changes in HA1 of type A (H3N2) virus. J Infect Dis 2001, 184 $542-546$

38. Belser JA, Gustin KM, Maines TR, Pantin-Jackwood MJ, Katz JM, Tumpey TM: Influenza virus respiratory infection and transmission following ocular inoculation in ferrets. PLoS Pathog 2012, 8: e1002569

39. Brown C: Blood collection from the cranial vena cava of the ferret. Lab Anim 2006, 35:23-24

40. Fox JG: Biology and Diseases of the Ferret, ed 2. Baltimore: Lippincott Williams \& Wilkins, 1998

41. Stark GV, Long JP, Ortiz DI, Gainey M, Carper BA, Feng J, Miller SM, Bigger JE, Vela EM: Clinical profiles associated with influenza disease in the ferret model. PLoS One 2013, 8: e58337

42. Music N, Reber AJ, Lipatov AS, Kamal RP, Blanchfield K, Wilson JR, Donis RO, Katz JM, York IA: Influenza vaccination accelerates recovery of ferrets from lymphopenia. PLoS One 2014, 9 : e100926

43. Belser JA, Gustin KM, Maines TR, Blau DM, Zaki SR, Katz JM, Tumpey TM: Pathogenesis and transmission of triple-reassortant swine H1N1 influenza viruses isolated before the 2009 H1N1 pandemic. J Virol 2011, 85:1563-1572

44. Paquette SG, Huang SSH, Banner D, Xu L, Leomicronn A, Kelvin AA, Kelvin DJ: Impaired heterologous immunity in aged ferrets during sequential influenza A H1N1 infection. Virology 2014, 464-465:177-183

45. Maines TR, Lu XH, Erb SM, Edwards L, Guarner J, Greer PW, Nguyen DC, Szretter KJ, Chen LM, Thawatsupha P, Chittaganpitch $M$, Waicharoen S, Nguyen DT, Nguyen $T$, Nguyen HH, Kim JH, Hoang LT, Kang C, Phuong LS, Lim W, Zaki S, Donis RO, Cox NJ, Katz JM, Tumpey TM: Avian influenza (H5N1) viruses isolated from humans in Asia in 2004 exhibit increased virulence in mammals. J Virol 2005, 79:11788-11800

46. Kuiken T, van den Brand J, van Riel D, Pantin-Jackwood M, Swayne DE: Comparative pathology of select agent influenza a virus infections. Vet Pathol 2010, 47:893-914

47. Zitzow LA, Rowe T, Morken T, Shieh WJ, Zaki S, Katz JM: Pathogenesis of avian influenza A (H5N1) viruses in ferrets. J Virol 2002, 76:4420-4429

48. Short KR, Veeris R, Leijten LM, van den Brand JM, Jong VL, Stittelaar K, Osterhaus A, Andeweg A, van Riel D: Proinflammatory cytokine responses in extra-respiratory tissues during severe influenza. J Infect Dis 2017, 216:829-833

49. Music N, Reber AJ, Kim JH, York IA: Peripheral leukocyte migration in ferrets in response to infection with seasonal influenza virus. PLoS One 2016, 11:e157903

50. Reber AJ, Music N, Kim JH, Gansebom S, Chen J, York I: Extensive $\mathrm{T}$ cell cross-reactivity between diverse seasonal influenza strains in the ferret model. Sci Rep 2018, 8:6112

51. Yamada M, Bingham J, Payne J, Rookes J, Lowther S, Haining J, Robinson R, Johnson D, Middleton D: Multiple routes of invasion of wild-type Clade 1 highly pathogenic avian influenza H5N1 virus into the central nervous system (CNS) after intranasal exposure in ferrets. Acta Neuropathol 2012, 124:505-516

52. de Wit E, Siegers JY, Cronin JM, Weatherman S, van den Brand JM, Leijten LM, van Run P, Begeman L, van den Ham HJ, Andeweg AC, Bushmaker T, Scott DP, Saturday G, Munster VJ, Feldmann H, van Riel D: 1918 H1N1 influenza virus replicates and induces proinflammatory cytokine responses in extrarespiratory tissues of ferrets. J Infect Dis 2018, 217:1237-1246

53. Belser JA, Maines TR, Gustin KM, Katz JM, Tumpey TM: Kinetics of viral replication and induction of host responses in ferrets differs between ocular and intranasal routes of inoculation. Virology 2013, 438:56-60

54. Zeng H, Goldsmith CS, Maines TR, Belser JA, Gustin KM, Pekosz A, Zaki SR, Katz JM, Tumpey TM: Tropism and infectivity of influenza virus, including highly pathogenic avian $\mathrm{H} 5 \mathrm{~N} 1$ virus, in 
ferret tracheal differentiated primary epithelial cell cultures. J Virol 2013, 87:2597-2607

55. Kang YM, Song BM, Lee JS, Kim HS, Seo SH: Pandemic H1N1 influenza virus causes a stronger inflammatory response than seasonal H1N1 influenza virus in ferrets. Arch Virol 2011, 156:759-767

56. Lakdawala SS, Jayaraman A, Halpin RA, Lamirande EW, Shih AR, Stockwell TB, Lin X, Simenauer A, Hanson CT, Vogel L, Paskel M, Minai M, Moore I, Orandle M, Das SR, Wentworth DE, Sasisekharan R, Subbarao K: The soft palate is an important site of adaptation for transmissible influenza viruses. Nature 2015, 526:122-125

57. Schrauwen EJ, Herfst S, Leijten LM, van Run P, Bestebroer TM, Linster M, Bodewes R, Kreijtz JH, Rimmelzwaan GF, Osterhaus AD, Fouchier RA, Kuiken T, van Riel D: The multibasic cleavage site in H5N1 virus is critical for systemic spread along the olfactory and hematogenous routes in ferrets. J Virol 2012, 86:3975-3984

58. Houser KV, Pearce MB, Katz JM, Tumpey TM: Impact of prior seasonal H3N2 influenza vaccination or infection on protection and transmission of emerging variants of influenza $\mathrm{A}(\mathrm{H} 3 \mathrm{~N} 2) \mathrm{v}$ virus in ferrets. J Virol 2013, 87:13480-13489

59. Wong SS, Duan S, DeBeauchamp J, Zanin M, Kercher L, Sonnberg S, Fabrizio T, Jeevan T, Crumpton JC, Oshansky C, Sun Y, Tang L, Thomas P, Webby R: The immune correlates of protection for an avian influenza H5N1 vaccine in the ferret model using oil-inwater adjuvants. Sci Rep 2017, 7:44727

60. Lee DH, Kim JI, Lee JW, Chung WH, Park JK, Lee YN, Han JS, Kim HY, Lee SW, Song CS: Quantitative measurement of influenza virus replication using consecutive bronchoalveolar lavage in the lower respiratory tract of a ferret model. J Vet Sci 2014, 15:439-442

61. Maines TR, Belser JA, Gustin KM, van Hoeven N, Zeng H, Svitek N, von Messling V, Katz JM, Tumpey TM: Local innate immune responses and influenza virus transmission and virulence in ferrets. $\mathrm{J}$ Infect Dis 2012, 205:474-485

62. Camp JV, Bagci U, Chu YK, Squier B, Fraig M, Uriarte SM, Guo H, Mollura DJ, Jonsson CB: Lower respiratory tract infection of the ferret by 2009 H1N1 pandemic influenza A virus triggers biphasic, systemic, and local recruitment of neutrophils. J Virol 2015, 89: $8733-8748$

63. Kirkeby S, Martel CJ, Aasted B, Vorum H: Carbohydrate determinants in ferret conjunctiva are affected by infection with influenza H1N1 virus. Curr Eye Res 2013, 38:1027-1035

64. Shinya K, Makino A, Hatta M, Watanabe S, Kim JH, Hatta Y, Gao P, Ozawa M, Le QM, Kawaoka Y: Subclinical brain injury caused by H5N1 influenza virus infection. J Virol 2011, 85:5202-5207

65. Imai M, Watanabe T, Hatta M, Das SC, Ozawa M, Shinya K, Zhong G, Hanson A, Katsura H, Watanabe S, Li C, Kawakami E, Yamada S, Kiso M, Suzuki Y, Maher EA, Neumann G, Kawaoka Y: Experimental adaptation of an influenza H5 HA confers respiratory droplet transmission to a reassortant $\mathrm{H} 5 \mathrm{HA} / \mathrm{H} 1 \mathrm{~N} 1$ virus in ferrets. Nature 2012, 486:420-428

66. Plourde JR, Pyles JA, Layton RC, Vaughan SE, Tipper JL, Harrod KS: Neurovirulence of H5N1 infection in ferrets is mediated by multifocal replication in distinct permissive neuronal cell regions. PLoS One 2012, 7:e46605

67. Centers for Disease Control and Prevention. Interim guidance for infection control within healthcare settings when caring for confirmed cases, probable cases, and cases under investigation for infection with novel influenza A viruses associated with severe disease. Atlanta, GA: CDC, 2016. Available at https://www.cdc.gov/flu/avianflu/novelflu-infection-control.htm (accessed November 18, 2019)

68. IOM. Preventing Transmission of Pandemic Influenza and Other Viral Respiratory Diseases. Edited by Institute of Medicine of the National Academies. Washington, DC: National Academy of Sciences, 2011

69. American Veterinary Medical Association. AVMA guidelines for the euthanasia of animals. Schaumburg, IL: AVMA, 2013. Available at https://www.avma.org/KB/Policies/Pages/Euthanasia-Guidelines.aspx (accessed November 18, 2019)
70. Siegers JY, van den Brand JM, Leijten LM, van de Bildt MM, van Run PR, van Amerongen G, Stittelaar KJ, Koopmans MP, Osterhaus AD, Kuiken T, van Riel D: Vaccination is more effective than prophylactic oseltamivir in preventing CNS invasion by $\mathrm{H} 5 \mathrm{~N} 1$ virus via the olfactory nerve. J Infect Dis 2016, 214:516-524

71. Lipatov AS, Kwon YK, Pantin-Jackwood MJ, Swayne DE: Pathogenesis of H5N1 influenza virus infections in mice and ferret models differs according to respiratory tract or digestive system exposure. J Infect Dis 2009, 199:717-725

72. Maines TR, Jayaraman A, Belser JA, Wadford DA, Pappas C, Zeng H, Gustin KM, Pearce MB, Viswanathan K, Shriver ZH, Raman R, Cox NJ, Sasisekharan R, Katz JM, Tumpey TM: Transmission and pathogenesis of swine-origin 2009 A(H1N1) influenza viruses in ferrets and mice. Science 2009, 325:484-487

73. Shinya K, Makino A, Tanaka H, Hatta M, Watanabe T, Le MQ, Imai H, Kawaoka Y: Systemic dissemination of H5N1 influenza A viruses in ferrets and hamsters after direct intragastric inoculation. J Virol 2011, 85:4673-4678

74. Glathe H, Hilgenfeld M, Lebhardt A, Strittmatter HU, Schulze P, Brandt B: The intestine of ferret: a possible site of influenza virus replication. Acta Virol 1984, 28:287-293

75. Basarab O, Smith H: Quantitative studies on the tissue localization of influenza virus in ferrets after intranasal and intravenous or intracardial inoculation. Br J Exp Pathol 1969, 50:612-618

76. Gustin KM, Belser JA, Wadford DA, Pearce MB, Katz JM, Tumpey TM, Maines TR: Influenza virus aerosol exposure and analytical system for ferrets. Proc Natl Acad Sci USA 2011, 108: $8432-8437$

77. Long JP, Vela EM, Stark GV, Jones KJ, Miller ST, Bigger JE: Early indicators of disease in ferrets infected with a high dose of avian influenza H5N1. Sci Rep 2012, 2:972

78. Xu L, Bao L, Deng W, Dong L, Zhu H, Chen T, Lv Q, Li F, Yuan J, Xiang Z, Gao K, Xu Y, Huang L, Li Y, Liu J, Yao Y, Yu P, Li X, Huang W, Zhao X, Lan Y, Guo J, Yong W, Wei Q, Chen H, Zhang L, Qin C: Novel avian-origin human influenza A(H7N9) can be transmitted between ferrets via respiratory droplets. J Infect Dis 2014, 209:551-556

79. Guarner J, Falcon-Escobedo R: Comparison of the pathology caused by H1N1, H5N1, and H3N2 influenza viruses. Arch Med Res 2009, 40:655-661

80. Riser BL, Maassab HF: Differential interaction of virulent and attenuated influenza virus strains with ferret alveolar macrophages: possible role in pathogenicity. J Infect Dis 1990, 161:699-705

81. van den Brand JM, Stittelaar KJ, van Amerongen G, Reperant L, de Waal L, Osterhaus AD, Kuiken T: Comparison of temporal and spatial dynamics of seasonal H3N2, pandemic H1N1 and highly pathogenic avian influenza H5N1 virus infections in ferrets. PLoS One 2012, 7:e42343

82. Vidana B, Martinez J, Martorell J, Montoya M, Cordoba L, Perez M, Majo N: Involvement of the different lung compartments in the pathogenesis of pH1N1 influenza virus infection in ferrets. Vet Res 2016, 47:113

83. Varble A, Albrecht RA, Backes S, Crumiller M, Bouvier NM, Sachs D, Garcia-Sastre A, tenOever BR: Influenza A virus transmission bottlenecks are defined by infection route and recipient host. Cell Host Microbe 2014, 16:691-700

84. Sun X, Belser JA, Pulit-Penaloza JA, Zeng H, Lewis A, Shieh WJ, Tumpey TM, Maines TR: Pathogenesis and transmission assessments of two H7N8 influenza A viruses recently isolated from turkey farms in Indiana using mouse and ferret models. J Virol 2016, 90: 10936-10944

85. Zhu H, Wang D, Kelvin DJ, Li L, Zheng Z, Yoon SW, Wong SS, Farooqui A, Wang J, Banner D, Chen R, Zheng R, Zhou J, Zhang Y, Hong W, Dong W, Cai Q, Roehrl MH, Huang SS, Kelvin AA, Yao T, Zhou B, Chen X, Leung GM, Poon LL, Webster RG, Webby RJ, Peiris JS, Guan Y, Shu Y: Infectivity, transmission, and pathology of human-isolated H7N9 influenza virus in ferrets and pigs. Science 2013, 341:183-186 
86. Belser JA, Lash RR, Garg S, Tumpey TM, Maines TR: The eyes have it: influenza virus infection beyond the respiratory tract. Lancet Infect Dis 2018, 18:e220-e227

87. Fujishiro T, Kawasaki H, Aihara M, Saeki T, Ymagishi R, Atarashi T, Mayama C, Araie M: Establishment of an experimental ferret ocular hypertension model for the analysis of central visual pathway damage. Sci Rep 2014, 4:6501

88. Jackson CA, Hickey TL: Use of ferrets in studies of the visual system. Lab Anim Sci 1985, 35:211-215

89. Hernandez-Guerra AM, Rodilla V, Lopez-Murcia MM: Ocular biometry in the adult anesthetized ferret (Mustela putorius furo). Vet Ophthalmol 2007, 10:50-52

90. Aamir UB, Naeem K, Ahmed Z, Obert CA, Franks J, Krauss S, Seiler P, Webster RG: Zoonotic potential of highly pathogenic avian H7N3 influenza viruses from Pakistan. Virology 2009, 390:212-220

91. Peng BH, Yun N, Chumakova O, Zacks M, Campbell G, Smith J, Smith J, Linde S, Linde J, Paessler S: Neuropathology of H5N1 virus infection in ferrets. Vet Microbiol 2012, 156:294-304
92. Pearce MB, Pappas C, Gustin KM, Davis CT, Pantin-Jackwood MJ, Swayne DE, Maines TR, Belser JA, Tumpey TM: Enhanced virulence of clade 2.3.2.1 highly pathogenic avian influenza A $\mathrm{H} 5 \mathrm{~N} 1$ viruses in ferrets. Virology 2017, 502:114-122

93. Zeng H, Goldsmith CS, Kumar A, Belser JA, Sun X, Pappas C, Brock N, Bai Y, Levine M, Tumpey TM, Maines TR: Tropism and infectivity of a seasonal $\mathrm{A}(\mathrm{H} 1 \mathrm{~N} 1)$ and a highly pathogenic avian $\mathrm{A}(\mathrm{H} 5 \mathrm{~N} 1)$ influenza virus in primary differentiated ferret nasal epithelial cell cultures. J Virol 2019, 93. e00080-19

94. Herfst S, Schrauwen EJ, Linster M, Chutinimitkul S, de Wit E, Munster VJ, Sorrell EM, Bestebroer TM, Burke DF, Smith DJ, Rimmelzwaan GF, Osterhaus AD, Fouchier RA: Airborne transmission of influenza A/H5N1 virus between ferrets. Science 2012, 336:1534-1541

95. Lakdawala SS, Shih AR, Jayaraman A, Lamirande EW, Moore I, Paskel M, Kenney H, Sasisekharan R, Subbarao K: Receptor specificity does not affect replication or virulence of the 2009 pandemic H1N1 influenza virus in mice and ferrets. Virology 2013, 446:349-356 